\title{
Enlightenment of American Associate Bachelor Degree and Community College Transfer System for Top-up of Associate to Bachelor in China
}

\author{
Weiguang Gao, Wu Zhang, Caiyun Hu
}

School of pine and field, Guangzhou University, Zengcheng Guangzhou, 511370,China

\begin{abstract}
Keywords: Vocational education, Top-up, Associate to bachelor convergence, Associate bachelor degree.
\end{abstract}

\begin{abstract}
With the development of society, people has increasingly higher requirements on diploma, and top-up problem is more prominent. Through the research on American community colleges, it is found that setting associate bachelor degree and transfer education system in community colleges can meet people's requirements on diploma , but also solve the problem of higher education convergence, providing enlightenment to solve our top-up education.
\end{abstract}

\section{Introduction}

Social and human development should be complementary and social development is inseparable from human development, human development cannot be independent from the social and economic development, and also education development. The concept of lifelong education proposed in all countries emphasizes on human development, and one of tangible sign of human educational development is to get a diploma. Higher level of education and diploma are the inherent demand of the general public, and to meet this demand is the responsibility of society. At present, the top-up education in China is surging but there also exists many problems. The following will discuss various aspects of top-up education.

\section{Brief Introduction to American Associate Bachelor Degree and Community College Transfer System}

\section{Degree Basic Information}

America is one of countries with the most developed higher education, and its higher education has reached the degree of popularity. Degrees include associate bachelor, bachelor, master and doctor. Basically, all countries in the world have the latter three degrees, therefore, associate bachelor degree seems distinctive. Canada, Australia, Thailand, Philippines, South Korea, and China's Hong Kong and Taiwan also set up the associate bachelor degree. British higher diploma is equivalent to an associate bachelor degree, but different from the domestic junior college diploma.

\section{Introduction to Community College}

American community college is a comprehensive higher education institution integrating transfer, vocational training, continuing education and community service and other functions. Its characteristics include, community property, openness, functional integration, low-cost, flexible forms of schooling; citizens living in the United States and aged at least 18 years can apply for admission without examination; students who complete their studies can obtain an associate bachelor degree and relevant professional certificates at the same time; its teaching quality is reviewed by the government-appointed or independent expert group to ensure meeting the requirement of transferring to a university. The number of community colleges accounts for $41 \%$ of colleges and universities. 
The number of students in community colleges accounts for $42 \%$ of the total students. State government requires undergraduate schools to reserve about one third number of juniors and seniors for community college transfer students. Generally, 20\%-30\% of students in colleges and universities are from community colleges. This system significantly improves the population proportion of American higher education ${ }^{[1]}$.

Courses setting focuses on close combination of social needs with economic and social development of the community, and teaching forms are flexible. According to students' cultural level, and professional direction they select, etc., colleges set up compulsory and optional courses with variety of contents, for different students to choose. Colleges use formal teaching, short-term tutorial class and concentrated training class and other teaching methods at the same time, and adopt various measures, including lectures, individual teaching, remote teaching and work-study program, to meet various needs of students ${ }^{[2]}$.

Students mainly come from this community, including ordinary workers, professional managers, waiters, etc., and after obtaining the associate bachelor degree, they still serve for the community. Thus, associate bachelor degree courses are rooted within the community and aimed at community service, to the maximum extent, to meet the needs of the community ${ }^{[2]}$.

\section{Status of Top-up Education in China}

In China, there is not associate bachelor degree system, and two-year technical secondary schools and three-year junior colleges do not grant degrees for graduates. With the continuous development and progress of society, junior college students and their parents have strong desire for top-up of associate to bachelor. And top-up ways are not only limited to national unified general education, but gradually become diversified. Junior college students can receive the bachelor degree through the following ways:

(1) Top-up of associate to bachelor in general colleges, also known as associate into bachelor, means after graduating from junior colleges, students participate in the unified examination, and ascend to the undergraduate universities according to relevant professions[3].

(2) Top-up of associate to bachelor of adult education, there are several modes, including, " $2+2$ " or " $3+2$ " mode, which means that after two or three years, junior college students complete college studies, through school counseling, pass undergraduate adult self-study examination; self-study adult examination for top-up; adult amateur correspondence course for top-up.

(3) Top-up of associate to bachelor of remote education (online education); Radio and Television University Open Education top-up.

(4) " $2+2$ " or " $3+2$ " associate to bachelor convergence, which refers to that after two or three years, junior college students complete college studies or relevant courses, and then directly enter application-oriented undergraduate universities with corresponding professions for junior and senior study, and obtain undergraduate diploma and bachelor degree after completion of their studies.

It can be seen that top-up education has furious competition between different forms. There are outstanding achievements, but also a lot of problems, therefore, it still can not meet people's needs.

\section{Construction of Top-up Education with Chinese Characteristics}

\section{Setting Associate Bachelor Degree}

In accordance with the development experience of higher education in developed countries, in the future China will popularize high school education, technical secondary school will tend to shrink, and higher education will tend to be popularized among the public, resulting in increasingly growing number of higher education persons. With the change of social needs, in order to meet the development demand of higher education, higher education should be able to meet the following requirements in the future. As long as students have the demand for further education and learning ability, they can successfully enter universities, and students whose ability is not sufficient, or 
because of employment demand, should be able to meet the vocational training requirements. To meet these requirements, referring to the successful experience of higher education popularization in the United States and other countries, we should set the associate bachelor degree. Many domestic experts and scholars in succession proposed to set associate bachelor degree in NPC \& CPPCC or other occasions, such as Liu Jingnan, member of CPPCC National Committee and academician; Cai Keqin, member of CPPCC National Committee and former vice president of China University of Geosciences (Beijing); Zhang Zhiyong, deputy to the National People's Congress and Shandong Province Education Department deputy director; and Qi Zaiqian, teacher in Beijing Union University ${ }^{[4]}$. Associate bachelor degree system will open up the training channel of junior college student and undergraduate education, and help achieve the mutual recognition and convergence of these two levels of education curriculum, conducive to the sound development of higher education.

Although China has not yet officially set the associate bachelor degree, but many schools have made useful exploration, such as, in 2009, Anhui Province Xiuning Desheng Luban Carpentry School awarded graduates "Carpenter Degree"; in 2012, Xiamen Huaxia Vocational College awarded graduates "Professional Associate Bachelor" degree; in 2013 Xunnan Communication Technician College awarded graduates "Carpenter Degree”; and in 2014, Hubei Vocational College awarded graduates "Skilled Degree” certificates ${ }^{[4]}$.

\section{Building Community Colleges}

Build community colleges. Currently, China's economy is in a downward trend and the deepened reform, and it is advised to timely promote to popularize higher education and implement the strategy of reinvigorating China through science and education. One of the effective measures is building community colleges. There are two ways, one of which is after the urban factory is moved out, and use the land for the construction of community colleges; the other of which is to transform various training institutions such as technical schools and vocational colleges into community colleges. Building community colleges can help popularize higher education, and its infrastructure can boost the economy. Basic assumption of community colleges is as follows.

(1) Community college is a comprehensive higher education institution, integrating transfer, vocational training, continuing education and community service and other functions;

(2) Unify curriculum codes, hours and credits, and teaching quality requirements, to provide the basis for transferring to four-year universities;

(3) Students can have courses of first two years in four-year universities or community colleges. Recommend to reserve considerable proportion of junior and senior undergraduates for community college transfer students;

(4) High school graduates can apply for admission to community colleges without examinations;

(5) Based on social needs, determine community college enrollment scale, the number of transfer students, top-up students and employment students, and give full autonomy for school running;

(6) Implement certification system. College Administration Department sets up or appoints neutral rating agencies, to assess community colleges, and only those who meet the requirements are qualified to transfer and grant the associate bachelor degree.

\section{Community College Curriculum Setting Balances Transfer and Vocational Education}

After the transition, community college courses, on the one hand, focus on courses of first two-year general education of higher education, connecting with courses of first two years in universities, and provide basic theory and basic technical education, so that students have opportunities to enter other educational institutions or higher level academies. On the other hand, according to the national industrial policy, industry development planning and regional economic development characteristics, give full consideration to the regional economy, set up technical and vocational courses based on demand, increase the proportion of practical courses and practice teaching, and prepare for employment of students who will not enter the higher school, and train various vocational and technical personnel urgently necessary for regional development. 


\section{Conclusions}

Through the research on national higher education popularization and practice in the United States and other countries and regions, we can find that the associate bachelor degree system and community college system can meet people's requirements on the diploma, but also solve the problem of higher education convergence, and provide an important reference value for our top-up education and the gradual popularization of higher education. The author believes setting associate bachelor degree and building community colleges are the most effective ways to solve the top-up problems in China.

\section{Acknowledgement}

This paper is Special Funded Project of 2014 Guangdong Education System Comprehensive Reform.

\section{References}

[1] Wan Yao. Enlightenment of Transfer Education in American Community Colleges for Top-up of Associate to Bachelor, Vocational Education Research, 2013.2

[2] LI Qiaozhen. Features and Enlightenment of American Community College Associate Bachelor Degree Courses, Vocational and Technical Education, 2005. 1

[3] Yuan Shi. Problems and Reform Proposals of General Colleges “Top-up” Education, Heilongjiang Education (Higher Educational Research and Evaluation) , 2010.4

[4] Li Yujing. Hugging Degree - Aspiration and Expectation of Vocational Education, Focus, 2014 